\title{
A spatial reading of urban political-religious conflict: contested urban landscapes in Addis Ababa, Ethiopia*
}

\author{
Jep Stockmans and Karen Büscher \\ 234 Anderson Hall P.O. Box I I7325 Gainesville, FL 326 I I; \\ University of Florida/ Universiteitstraat 8, 9000 Gent, Belgium; \\ University of Ghent
}

Emails: stockmansjep@ufl.edu/Karen.Buscher@Ugent.be

\section{A B S T R A C T}

This article presents a spatial approach to the recent history of conflict and confrontation between the Ethiopian Government and Ethiopian Muslim Communities in Addis Ababa. Based on original ethnographic data and inspired by existing academic studies on political-religious relationships in Addis Ababa, this study takes a closer look at the significance of the urban public landscape in power-struggles between the EPRDF and the Muslim communities. The article argues that political-religious struggle in Addis Ababa shapes the current urban landscape, as use of and control over urban public space and place forms a crucial element in the strategies of public authority of all involved actors.

\section{N T R O D U C T I O N}

The starting point of this article is the current climate of tension and confrontation in the capital city of Ethiopia, Addis Ababa, between urban Muslim communities ${ }^{1}$ and the Ethiopian government (or the EPRDF). ${ }^{2}$ These relations have not always been as conflictual as they have become since 2011. When the EPRDF took control over Ethiopia

* This fieldwork was made possible by VLIR-UOS ('Vlaamse Inter-universitaire Raad Universitaire Ontwikkelingssamenwerking') which awarded us with a research scholarship to perform fieldwork. Locally, we have worked in close collaboration with the Institute of Ethiopian Studies. 
in 1991, it replaced the Derg regime ${ }^{3}$ and announced a total break with the previous political regime employed by the communist rule and the previous emperors and Amharic elites. The EPRDF introduced 'ethnic and religious freedom' in its new constitution (Van der Beken 2010) 4 and for many Ethiopian Muslims, this announced the beginning of a new era in which they would be freed from what they perceive as centuries of discrimination and treatment as second-class citizens (Hussein 1993). During the first five years, the EPRDF realised considerable improvements to the social, political and religious conditions of Ethiopian Muslims (as well as Christians), 5 especially within the region of the capital city. A new mayor of Addis Ababa with an Islamic background assumed power and he intensely reinforced the political and spatial presence of Islam in town. During his four-year tenure as mayor, 30 mosques were being constructed, multiple Islamic institutions were erected and Ethiopian Muslims were allowed to perform religious rituals in public (Sumeya 2012) ${ }^{6}$ From the second half of the 199os, however, mutual perceptions and attitudes between the EPRDF and the Ethiopian Muslim communities started to change. Increasing frictions emerging from a number of local, regional as well as globally influenced dynamics eventually resulted in structural distrust, conflict and (sometimes violent) confrontation. At present, this confrontation has taken the shape of a sharp opposition, with the government proclaiming its fight against Islamic extremism, and the Muslim communities proclaiming their resistance against government repression and its interference in religious affairs (Abbink 2014a).

According to Jon Abbink, this controversy between Muslims and the state 'is in itself nothing new and reflects a pattern of competition and political claim making well known in Ethiopian history' (Abbink 2014a: 347). Today's conflictual relationship has to be framed within broader historical dynamics of political-religious struggle in the capital city and the country in general (Hussein 2007; Østebø 2010; Feyissa Dori 2013; Stockmans 2014). Academic research focusing on this struggle has analysed the political and socio-economic effects of these conflicts in Addis Ababa in detail (see for example Hussein 2006; Østebø 2013; Abbink 2014a). One aspect that has received relatively little attention in these studies is the aspect of space and place; although some scholars have pointed at spatial outcomes of current struggle between the Ethiopian government and Ethiopian Muslims, none have considered the dialectical relationship between the dynamics of political/religious conflict and the dynamics of space/place-making/ unmaking. 
Starting from a concrete urban case study, this article offers a spatial reading of the on-going conflicts between the Ethiopian government and the Muslim communities in Addis Ababa by focusing on their spatial strategies of public authority, power and control. By putting particular focus on 'spatial agency', the authors will demonstrate how the urban public space is used by both actors to reinforce themselves and/or undermine the other. We argue that the active shaping and reshaping of the urban public landscape is an important political mechanism in the current struggle for control and representation, and that studying the urban landscape of Addis Ababa is an insightful way to better understand the ways in which power and authority are produced within the current setting. In the case of the EPRDF, on the one hand, spatial agency takes the form of strategies of control, monitoring, curtailing and repressing Muslim's claims to the urban space. On the other hand it is exercised by spatial manipulations making Muslim public space increasingly invisible. In the case of the Muslim communities, spatial agency is expressed in their material and immaterial 'politics of presence'.

This study consists of a historical-political ethnography of the spatialities of political-religious conflicts in Addis Ababa. Since many of the recent frictions and conflicts between the Ethiopian Muslim-communities and the EPRDF unfold themselves in the urban context, the choice for an urban case-study approach is a straightforward one. Addis Ababa presents a perfect case given its particular political history and the historical influence of religious actors on shaping local urban society. This paper is based on a thorough literature review, 7 combined with first-hand data collected during ethnographic fieldwork in Addis Ababa between January-March 2014. Apart from gathering information through qualitative research methods such as in-depth interviews and participant observation with various groups of informants, secondary resources were also actively consulted, including local archives, local newspapers, government documents, blog posts, satellite images and maps. Ethiopian Muslims, from different movements, formed the main group of informants for this research (academics, journalists, street vendors, etc.), although many interviews were also held with non-Muslim urban inhabitants, local administrative authorities and government representatives.

After situating our topic within the relevant theoretical frameworks and academic debates, we present a short historical reconstruction of the complex relationship between the Ethiopian government and the Muslim communities of Addis Ababa. Subsequently, we investigate the spatial aspects of current confrontations and analyse the role and function of urban public space in the dynamics of (violent) power struggle. 
The spatial turn in political science and conflict studies has taught us how to apply space as an analytical tool in the analysis of political struggle. By understanding space and place as tools of political power or agency, we have been able to observe how power circulates through space and (urban) landscapes. ${ }^{8}$ The specific spatial patterns or dimensions of political-religious conflict in Ethiopia have been touched upon by a number of scholars working on Addis Ababa (Desplat 2005; Abbink 2011; Feyissa Dori 2011). This study is particularly inspired by the fascinating work of Patrick Desplat (2005; Desplat \& Schulz 2012) on mechanisms of place-making by Ethiopian Muslim communities, being the first scholar to use a specific urban approach in this domain. However, where Desplat exclusively focuses on Muslim agency in terms of place-making, our study investigates the function of urban public space in spatial agency on both sides in conflict, thus also including the Ethiopian government (EPRDF). The Ethiopian regime is equally engaged in spatial interventions and manipulation of the public material and political cityscape, by for example pushing religious infrastructures such as mosques to the urban periphery. The specific case-study of struggles over material and political urban space in Addis Ababa demonstrates the mechanisms of spatial modes of urban governance. In line with political geographer Doreen Massey's interpretation of spatial agency and the relationship between transformation of space and management of power, we will argue that the use and transformation of public space is part of the political mechanisms of power and control (Massey 2005; Büscher 2015). As such, the struggles over urban public space in Addis Ababa are analysed here as an outcome of the 'politics of spatial agency' (Sadeh 2010).9 This spatial agency lies in the practices that create, reconfigure or undermine the public space, in the actors that plan them, the laws that legitimise them and the discourses that shape them.

Different scholars have elaborated on the geographies of religion and the religious production of space in which the case of the struggle between the Muslim communities of Addis Ababa and EPRDF can be situated (Kong 1990, 2001; Holloway \& Valins 2002; Gale 2004). This spatial analysis of religion has demonstrated the critical importance of 'locations in which religion resides' (Olson et al. 2013: 5): the individual, institutions, objects, mosques, public media and more. The material urban spaces such as mosques, or public religious practices such as 
wearing a veil in public, are both crucial in daily routines of the Muslim communities in Addis Ababa, at the same time symbolising the communities' presence, representation and power in town. ${ }^{10}$ It is crucial to understand how the religious production of space often is in itself a political act (Garmany 2010); Ethiopia is a clear example of how the presence and growth of Islam has become a very political debate. What the case of Addis Ababa will further illustrate is how the politics of religion are spatially translated (Gale \& Naylor 2002; Desplat \& Schulz 2012). Arguing that spatial agency is a political practice helps us to understand the current events in Addis Ababa where the relation between politics and religious space has been creating, transforming and pulling apart urban space and place.

Cities do not only present ultimate arenas of political contest, but also represent extended variations of public space in terms of physical infrastructure or media, for example (Büscher 2012). In Ethiopia, Addis Ababa - with its well-developed government infrastructures, security forces and religious institutions - represents a unique arena of religious mobilisation and statehood. As the capital city, and the largest city in Ethiopia, Addis Ababa embodies a fascinating concentration of multiple cultures, identities, ethnicities and languages. As is the case for capital cities worldwide, it is here that political struggles are fought; it is in the capital city that government as well as religious institutions are most visible and their mechanisms of presence, dominance and authority the most pronounced. In their urban context, religious urban spaces and places matter politically, economically and socially. Researchers such as Desplat have clearly indicated that economic, social and political activities in and around religious spaces are important to consider in an analysis of space-making in cities such as Addis Ababa; further, as he states, 'Muslim practices of place making are often intensified to manoeuvre through the complexities of urban life' (Desplat in Desplat \& Schulz 2012:12).

INCREASING CONFRONTATIONS B E T WE N E PRDF AND E THIOPIAN MUSLIM COMMUNITIES IN ADDIS ABABA

Around $40 \%$ of the present Ethiopian population is Muslim. ${ }^{11}$ The Ethiopian Muslim communities consist of a range of movements, all very different with regards to ideology and practice. ${ }^{12}$ In Addis Ababa, the four largest Islamic movements are: (1) the Salafist movement (in Addis Ababa mainly represented by the Ethiopian Muslim Youth 
Association) which is currently perceived by many as a more 'radical' movement; (2) the Sufism-inspired Jamat al-Tabligh movement (the biggest in Ethiopia); (3) the Intellectualist Movement which has its origins in the ideas of a collection of Islamist movements (including the Muslim Brotherhood); and (4) Al-Abbash, the governmentpromoted 'moderate' Islamic movement (Østebø 2008, 2010; Abbink 2014a). ${ }^{13}$ The Muslim population of Addis Ababa is generally linked to certain areas and neighbourhoods in town. Muslims living close to one another often try to construct local institutions like mosques and schools, representing important centres around which their daily life is organised (Masud 2000). These areas do not form homogeneous blocks and they can be internally quite fragmented. The way in which different groups of Ethiopian Muslims engage with the public space in Addis Ababa can be different, given the fact that they historically occurred in different spatial and cultural contexts within Ethiopia (Østebø 2008).

With regard to Muslim settlements in Addis Ababa - following patterns of migration - Muslim communities tend to be strongly represented in particular urban neighbourhoods (Abdulwehab 2011). ${ }^{14}$ The sub-cities or boroughs of Addis Ababa: Addis Katema, Kolfe Keranyo, Gulele and Lafto, are generally known to be places with the highest Muslim concentrations and a significant number of mosques or Muslim-dominant markets. Only Addis Ketama is located in the centre of the city; in this sub-city one finds the Muslim-dominated market Merkato. The other sub-cities are closer to the periphery of Addis Ababa, since they were added later in the urban planning. The ideological correlation between the different Muslim communities and these sub-cities is not straightforward as they present a 'scrambled' presence of Muslims from different movements. Yet, some areas such as Gulele are commonly perceived as dominantly Tablighi given their historical presence. ${ }^{15}$

All Islamic movements blossomed in Ethiopia during the early reign of the EPRDF, in particular the Salafist movement saw a spectacular growth, no longer faced with restrictions with regards to its activities and exchanges with Saudi Arabia. ${ }^{16}$ The regime's initial support to the Muslim communities in an attempt to curb the power of the (mainly Christian) Amharic elites resulted in a big expansion of Muslim religious education, media and culture. Muslims occupied more prominent political and governmental positions. Islamic NGOs, associations and institutions were erected, Friday public office hours were adapted to the mosque prayer-times (Abbink 2011), and in 2012 
a local scholar noted that 105 of the existing $15^{8}$ mosques in Addis Ababa had been built after the EPRDF took power in 1991 (Sumeya 2012). However, the image of the EPRDF as an allegedly "pro-Muslim party' ${ }^{17}$ that emerged from this support did not survive long. Today, relationships between the EPRDF and Islamic movements in Addis Ababa are characterised by deep distrust, sharpened by the governments' current battle against Islamic 'radicalisation'.

Since the mid 1990s, a number of incidents have marked this deteriorating relationship. Østebø (2010), Feyissa Dori (2013) and Abbink (2014a) have described in detail these moments that are locally and internationally perceived as fundamental in the changing attitude of the EPRDF and the changing discourse on Islam in Ethiopia. Many Muslim demonstrations and confrontations with the government occurred around the contestation over the Majlis (or Ethiopian Islamic Affairs Supreme Council, EIASC), the only governmentsupported organ for Ethiopian Islamic socio-political representation and protection in Addis Ababa. The regime has increasingly tried to co-opt this institution, leading to a gradual loss of its legitimacy in the eyes of the Muslim communities. ${ }^{8}$ From 2011 onwards, through the body of the Majlis, the Ethiopian government started organising trainings and 'reformist' conferences 19 in Addis Ababa aiming at more 'moderation and religious tolerance' (Abbink 2014a) by explicitly promoting the al-Ahbash movement (and, by extension, denouncing Salafism in Ethiopia which was considered both by the government and the alAhbash movement as extremist). By promoting this regime-controlled form of Islam through ideological training sessions, the government used an ultimate strategy of control to regain power over the Muslim communities (Østebø 2013; Abbink 2014a). ${ }^{20}$ This al-Ahbash 'indoctrination' was answered with a structural urban-based resistance and wave of demonstrations by the different Muslim-communities who collectively turned their back against EPRDF. The co-optation of the Majlis also resulted in an increasing informal organisation of Islamic associations, escaping the control of the central government (Østebø 2010).

The wave of conflicts and confrontations since $2011^{21}$ between the Muslim communities of Addis Ababa and the Ethiopian Government can be read as state repression of Muslim activism; the government itself has framed these efforts as 'tackling Islamic extremist discourse and practices'. Muslim communities however, have experienced this as a threat to their religious freedom. In their fight against what EPRDF perceived as 'radicalisation tendencies', the government took 
different, similarly contested actions to secure its control over the communities. A clear tendency through these actions can be observed in the repression of the Salafist movement. The most explicit example is the government 'cleansing' of the Salafist Aweliya College (and by extension the Aweliya Mosque) in Addis Ababa by putting it under Majlis jurisdiction, ${ }^{22}$ dismissing fifty staff members (including all Arabic teachers) and abolishing the Arabic curriculum. ${ }^{23}$ In response, student protests broke out from the Aweliya College, massively supported by a large part of the urban Muslim communities, reinforced on social media, against alAhbash and the Ethiopian government. ${ }^{24}$

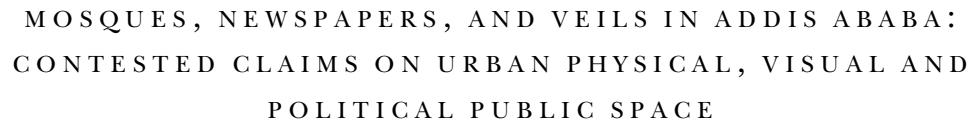

Just like many African cities today, Addis Ababa, with its estimated $3 \cdot 4$ million inhabitants, ${ }^{25}$ is characterised by a rapid demographic and geographic expansion (Addis Ababa is 15 times bigger than the second largest Ethiopian city). A largely informal urban economy is an answer to huge formal unemployment (Di Nunzio 2012). The urban landscape is further marked by large areas of informal settlements ${ }^{26}$ as well as several on-going slum-upgrading projects as well as neo-liberal urban developments. ${ }^{27}$ The Ethiopian regime is ever present in public urban life in the form of the police force, the large military base in the midst of the city, the strong centralisation of its administration, and tight control on organisational life. Furthermore, the government is visually present in the public space through billboards with nationalist propaganda and several important open squares which are decorated with party banners and flags. An example is Meskel Square, the ultimate place of public gatherings in Addis Ababa where the life of the first EPRDF prime Minister Meles Zenawi is remembered extensively. In general, it has further been observed that the Ethiopian state has increasingly narrowed the space for public engagement of civil society, opposition parties and - to some extent - the private sector (Planel \& Bridonneau 2015).

Religion is very present in the public sphere of Addis Ababa and functions as a 'key framework for community life' (Abbink 2011). ${ }^{28}$ Public space in Addis Ababa, as in other urban centres of Ethiopia, is marked by inter-religious competition over the public space. This is often literally translated into competition over when and where to build mosques, 
churches or chapels; self-presentation in the media; public celebrations; and religious 'noise' production by means of loudspeakers (Abbink 2011). In our attempt to describe how the power games between the Ethiopian government and the urban Muslim communities are fought out in terms of urban spaces and places, we will similarly approach Addis Ababa's public space from two different angles: on the one hand we will focus on the 'hardware' - the material urban landscape mainly in the form of religious infrastructure; on the other hand we will focus on the 'software' or the claims to the political public space in the form of public demonstrations, media profiling and religious public practices and performances.

Different movements within the Muslim community have their own particularities engaging in the public space. For example, more than any other movement, the Intellectualist Movement is intrinsically 'urban' in nature, 'home grown' in Addis Ababa and led mainly by educated youth. Their engagement with politics is more explicit than other movements, notably in contrast with Jamat al Tabligh, who tend more to avoid political debates. Since, according to the Intellectualist Movement, Muslims are expected to be engaged in all sectors of social and political life (Østebø 2008), this movement is often well represented in urban protest movements, making explicit political claims on social media, publications and graffiti. While the Intellectualist Movement has the university as its urban spatial base, for the Salafist movement, this base is much more the mosque, or for the Tabligh the bases can be found in the trading centres around Merkato Market. With regards to religious education, audio and video material, or dress-codes, many public debates revolve around the Salafi dominance, which can be partly explained by the increasing political attention towards this particular movement. With regards to their spatial visibility, for example, the Salafi garb makes them very distinguishable in the public sphere. Some Salafi women will wear the Niqab while many other Muslim women will wear the hijab. Similarly, some Salafi men often distinguish themselves by their beards and pants that show their ankles, while other Muslims will wear the Thawb or white dress more regularly.

\section{Legal battles to construct a mosque}

Mosques, Islamic schools and shrines are often metaphors of representation and prominence. They function as spatial signatures of Muslim presence in the city and are an important element in Muslim's spatial politics of presence. Furthermore, much of these mosques' actual 
significance in people's daily lives results from the social actions of people "who imbue the physical structure of a locality with specific meanings and functions' (Desplat \& Schulz 2012: 19). Thus, apart from the material manifestation of urban religious infrastructure, it is also important to pay attention to the daily routines and activities of the people surrounding these places. We might point, for example, to the numerous Muslim shopkeepers operating around mosques, and other daily practices of 'place-making' by ordinary citizens. ${ }^{29}$

When looking for mosques in Addis Ababa, one needs to look beyond the restricted image of classic domes and minarets. Most of the time, mosques take the form of regular houses and are often part of private property. This can partly be explained by complex procedures to be granted land titles or formal construction permits, procedures which are often corrupted or partly informal. Locally, this is also repeatedly explained, mainly by Muslims, by the fact that the government allegedly hinders the construction of mosques in the capital city (Abdellah 2007; Abdulwehab 2011; Sumeya 2012).30 This forces several mosques to operate informally, without any licence, from the outside almost unrecognisable (Sumeya 2012). In 2012, only $5^{6}$ out of $15^{8}$ mosques in Addis Ababa were officially registered and were operating with a formal licence. From the interviews with different respondents in Addis Ababa, the refusal of providing licences for Ethiopian mosques in Addis Ababa is perceived as an active strategy of the government, legitimising possible future legal actions in order to shut down these religious institutions. In case the EPRDF were to change their mind on a plot of land (for purposes of urban planning or developmental agendas) this could provide legal grounds for removing mosques operating without any legal framework. ${ }^{31}$ The consequence of forcing these institutions to operate informally is a total lack of legal protection for the structures that are used as mosques. Moreover, since they are not officially recognised as mosques in the first place, from the government's position these (informal) constructions are not legally mosques to begin with. As such, the prayer in general and more importantly Friday prayer cannot be officially organised in these mosques, and the government thus forces Muslims to operate informally, curtailing their material and visible presence in the urban landscape. ${ }^{22}$ To give another example: only 40 of the 105 mosques constructed since 1991 were given a plot of land to construct their mosque by the government (Abdellah 2007). According to an employee at the municipality of Addis Ababa, there are no plots of land foreseen in the current city planning for the construction of religious buildings in Addis Ababa. Whoever 
wants to construct a religious institution in Addis Ababa should introduce a demand for construction at the municipal level, the government will accord the land after investigation. 33 The Ethiopian government, by intervening in construction plans for mosques, deliberately hinders the spatial presence and expansion of Muslim communities in Addis Ababa. The EPRDF obstructs their spatial agency by instrumentalising legal procedures of allocation of land (by granting permissions, taking back permissions, or granting permissions to several applicants for the same plot). Although this has never been officially confirmed by the government, this tenure insecurity is generally understood as a complex mechanism used by the regime to confirm their control over the cityscape and to weaken Muslim claims to it.34 Interestingly, the outcome of the government-driven de-institutionalisation of Islam has been the increased importance of mosques as crucial bases of religious recruitment by Muslim communities. Yet, this fragmentation of spatial anchoring of Islam in the urban social and political landscape poses serious challenges to the Ethiopian government, as scattered mosques are much more difficult to 'control' then a centralised institution (Østebø 2008).

Another interpretation for the regime's motivations behind these mechanisms has been the EPRDF's consistent efforts to present itself as a secular state, in which religion is reduced to the private sphere (Østebø 2013). However, since the EPRDF has been in power and has constituted religious freedom, the opposite has been observed, in the form of an increase in religious public presence (Stockmans 2014).

Constructing new mosques has proved to be a long and complex procedure, frequently involving conflict. This is well illustrated by the often-heard expressions among Muslims in Addis Ababa such as 'for the construction of every mosque blood has to flow' or 'for every mosque someone has to die'. 35 This, of course, is exaggerated; the government in some cases does support the Muslim communities in their spatial expansion. However, it cannot be ignored that a large number of mosques in Addis Ababa were only built after long and exhaustive legal battles with government bodies responsible for granting the plots of land, issuing the necessary title deeds and permits for construction (Abdulwehab 2011). Some examples are very illustrative in this regard.

In 1996, the local Muslim committee wishing to construct the Bilal mosque introduced a demand at the municipality for permission to construct on a plot of land in the western part of Addis Ababa (Addis Ketama). They were left to wait for several years and in the meantime a small temporary mosque was erected. When in 2000 the government eventually replied, the land turned out to have been sold in the 
meantime, to a private investor. The community was told that the temporary mosque had to be destroyed within five days, if not a demolition crew would be send by the government. In response, the local Muslim community demonstrated against this decision. Eventually, in 2004, the government gave in to the pressure and demands, and granted the land for the construction of Bilal mosque. The construction was finalised in 2012, 16 years after the initial request for permission (Sumeya 2012). $3^{6}$

Another similar example is that of al-Fatih mosque, for which the local Muslim community had to wait 17 years for a construction permit. As was the case for the Bilal mosque, while the request was pending, the land had been sold by the government to a private investor. The temporary mosque, which was built out of frustration after several years of waiting, was to be demolished and the community had to pay a 200,000 Birr fine based on illegal construction.37 Today it has been rebuilt on another piece of land with permission of the Ethiopian government (Abdulwehab 2011).

Finally, there is the long history of Sumeia mosque. The first efforts to construct the mosque in 1975, under the Derg regime, were violently obstructed by the government. $3^{8}$ The scholar that instigated the application for a construction permit in 1975 was arrested and served a sentence in prison. His son, who later took over the campaign to build the mosque, disappeared in 1979 and was never seen again. In 1992, the new regime agreed to the construction, yet no formal consent was given. The government contacted the community and through a letter confirmed the approval of their construction permit. However, the permit itself was never actually produced and granted to the community. 39 In 1995, it was announced that the plot requested to construct the mosque had been allocated for the construction of a private school. In 2000 a new request was introduced and in the meantime, a private house was rented that would serve as a temporary mosque. However, the moment the Christian owner became aware of the Muslim activities on his property, he ordered them to leave. The community refused and occupied the house for almost two years until the government forcefully intervened, leaving five dead and 120 injured (Abdellah 2007; Abdulwehab 2011).40 Shortly after this incident, the government allocated a different area in the city for the construction of Sumeia mosque. $4^{11}$ However, as turns out is often the case, this plot was located in a former rubbish dump in the borough of Yeka. Fetah Abdellah, who has done research on this phenomenon, states that 90\% of the mosques in Addis Ababa have been constructed near a 
gorge or a place that used to function as a rubbish dump (Abdulwehab $2011)$. A number of scholars who have done research on the history of mosques in Addis Ababa claim that there is an active policy within the Ethiopian government to locate mosques in Addis Ababa on pieces of land which are not suitable, to avoid large concentrations of mosques in the city centre (Abdellah 2007; Abdulwehab 2011; Sumeya 2012).

By allocating plots in the urban periphery and by dragging out the process for acquiring formal licences, permits and titles, the government regularly leaves mosques in a marginal and informal position in Addis Ababa. Mosques, that are intended to be physical reminders of a religious presence, power and visibility, thus become invisible and unrecognisable in the form of hidden, informal prayer rooms in regular houses. If the Muslim communities react by making these informal mosques more 'visible' (by spatial and vocal performances, for example), their informal position and tenure insecurity makes them extremely vulnerable to government interventions and expulsion on the basis of 'illegal' status. Studies on informal processes of urbanisation in other cases in urban Africa have demonstrated that corrupt practices of land regulation are an important element of urban elites' strategies of dominance and power (Locatelli \& Nugent 2009). The politics of land allocation are being used in many African cities to exclude or marginalise potential threats to the dominant public authority, and are one of the most effective tools to define who has a 'right to the city' and who does not (Mabin 1989; Jenkins 2009). Further, from these examples also emerges how the material attempts to claim the public space are pushed back by the Ethiopian government in the name of urban development, by allowing private actors (companies, development agencies, private schools) to access land that is requested by the religious community. As has been demonstrated by a number of scholars, through the logic of the 'developmental state', the facilitation of neo-liberal private urban development is an integral part of the EPRDF strategies of state formation and reinforcing legitimacy for the authoritarian state (Lefort 2012).

\section{Claiming the urban public space by ritual practices and performance}

The Friday prayer is the most prominent demonstration of the presence of the urban Muslim communities in Addis Ababa's cityscape. At the Friday communal prayer, Muslims gather in and around the larger mosques in town that have the capacity to host large numbers of people. But this space is often not large enough, and the obvious 
shortage of mosques in the city to host all Addis Ababa Muslims leads at times to hundreds of Muslims gathering in the streets around these mosques to perform the prayer (Stockmans 2014). In such places as the Beni Mosque, located close to Merkato, the overflow of Muslims during prayer time is extensive; the streets surrounding the mosque are completely filled with prayer rugs from sidewalk to sidewalk. All surrounding streets are cut off because there is literally no sign of the asphalt road underneath the prayer rugs. The two streets surrounding the Beni Mosque, including the roundabout in which these streets end, are completely occupied. A third road also ending at this roundabout is partially used by people who arrived late to the call to prayer from the Beni mosque. Before Friday prayer takes place there is the extensive performance of ablutions ( $a l-W u d u)$ which is also done in the streets due to lack of inside infrastructure. After the Friday prayer is performed it takes about an hour for everyone to clear out of the mosque and its surrounding public space. During the prayer, the government usually closes off the street. These prayers are accompanied by an extensive police presence deployed by the state, $4^{2}$ ostensibly because the total occupation of the streets requires police to monitor traffic, but a presence which is locally interpreted as a way for the government to closely monitor the Friday prayer. 43

Not only the police, but also non-Muslim urban inhabitants, increasingly display irritation at Muslim public praying in the streets. There are reported incidents in which Muslims who were praying in public spaces were chased away by police, or harassed by other citizens (Abdellah 2007).44 During the construction of Jafar mosque, for example, there was an incident during which local Muslims praying on a stretch of grass in anticipation of the mosque were called 'dogs' and 'foreigners' by bystanders (Abdulwehab 2011). Another case where taxi drivers decided to pray next to their cab under one of the Addis Ababa bridges resulted in them being chased away by the police. 45 This growing frustration with public prayers is locally explained by the increasing sense of suspicion towards Muslim presence and practices in Addis Ababa, reinforced by local media representations of Islam in relation to extremism and terrorism.

Prior to the fall of the Derg and the arrival of the new Ethiopian regime, Muslims were only allowed very restricted ritual expression, not only in terms of public prayers and but also in terms of expression through clothing and ritual performance. Before 1991, it was rare in Addis Ababa to see Muslims praying in the streets or wearing traditional Muslim dress. Today Ethiopian Muslims are visibly present in the urban 
public space. Women wearing the Hijab and some Salafi women wearing the Niqab increase the visibility of Islam in the public space, providing striking contrasts with the dominant historical presentation of Ethiopia as a 'Christian nation'. After the liberalization of religion in 1991 there was a huge increase in Islamic religious garb. Women in particular have returned to the use of veiling, in the context of new access to global Islamic discourses resulting from this liberalization (Østebø 2010). The extensive use of the veil after 1991 is an interesting phenomenon, whose expansion can largely be explained by a new emphasis on piousness by reform movements like Salafism. However, the donning of the veil is accepted and even required by most interpretations of Sunni Islam and is thus often presented as an effort by women to be pious and respected Muslims. $4^{6}$

This effort to claim the urban space in the form of increasing public presence and visibility has been met with various responses. In 2009 the EPRDF introduced a law prohibiting the headscarf for women, and prayer on the campuses of schools and universities. Bahir Dar University, for example, has prohibited the hijab and niqab since 2013. The law is justified in terms of the notion of the secular state and the separation of education and religion, as provided for in the 1995 constitution. Yet, as is constantly pointed out in Muslim protests, many Ethiopian Muslims experience this as a violation of the notion of freedom of religious expression which is equally spelled out in the constitution. 47

\section{Struggle over the political urban space}

As the capital city, Addis Ababa represents the ultimate administrative and political centre of the country, in which the state presence and influence is at its strongest. Logically, the capital city thus is ultimately an arena where political discourses are produced and reproduced by the regime as well as by religious institutions. The public expression of religion has become a political debate in different ways. First of all, it challenges the dominant state narratives of secularism in Ethiopia. Secondly, in the light of the post 9/11 political landscape, debates on the Islamic presence and spatial (as well as social and economic) expansion is more politicised than ever. Finally, faith has become an increasing political resource in Addis Ababa and Ethiopia in general, where political opposition has actively capitalised upon faith-based anti-government sentiments.

Contestation over political space in Addis Ababa is well illustrated by the case of public demonstrations. Demonstrations led by the Ethiopian 
Muslim communities in the city of Addis Ababa are nothing new. As was also the case during the Derg regime, demonstrations have been used by the different Muslim communities as an important means to put forward their demands toward - and critiques against - the Ethiopian government. Over the last 10 years, the pressure to export religious demands to the public space was met with increasing controversy and resistance (Abbink 2014a). The impact on the urban public space is obvious: large numbers of Muslims gather in the streets, marching, singing and shouting, making it impossible to ignore them. This form of Muslim political agency as such is also a form of claiming space, not only to put pressure on the government but also to make other urban inhabitants aware of their problems and frustrations. $4^{8}$ As mentioned earlier, younger Muslim generations are today much more involved in politics, and follow different, more political versions of Islam. The growing urban based, wealthy middle class of politically active Muslims (such as many in the intellectualist movement) has a strong influence on the contestation over political public space between the state and the Muslim communities.

The protest movements, such as those that emerged after the Aweliya incidents, gather different Muslim factions, although the Salafist movement is often explicitly present given the fact that it feels particularly targeted by government policies. 49 The Aweliya incidents were followed by two years of regular mass demonstrations, supported by parts of the Christian communities and opposition groups. The Muslim communities formulated three demands: the return of the college 'to the people', elections for the Majlis (eventually accepted by the government) and a halt to the enforced indoctrination of al-Ahbash (Jawar et al. 2013; Østebø 2013). The demonstrations grew into a broad Muslim protest movement against the increasingly intrusive approach to Islam of the government. This 'movement' was mainly organised by the so-called 'arbitration committee' representing a broad spectrum of the different Muslim communities (Østebø \& Shemsedin 2015). As elsewhere in Africa and all over the world, these political demonstrations are a clear urban phenomenon. They usually take place in the centre of the city around Anwar mosque (the most important mosque in Addis Ababa, located within the Merkato market in the sub-city Addis Ketama). These demonstrations were often met with fierce repression by the army and police, and the arrests of many protesters and representatives of the movement (Jawar et al. 2013) ${ }^{5^{\circ}}$ led to a gradual decline in the weekly demonstrations after two years. ${ }^{51}$ Yet, the movement is still very active on social media, $5^{2}$ and sporadically calls for demonstrations. 
As such, in a way, the spatial agency in the form of political demonstrations has been partly 'relocated' from the streets to the internet.

The passing of a controversial anti-terror law in 2009 has further enabled the Ethiopian government to crack down on any movement against the regime, whether religious or politically motivated $(\varnothing$ stebø 2013). Demonstrators can be arrested at any time for 'inciting terror and instability'. On 6 July 2015, the Ethiopian Federal High Court convicted a number of leaders of the Ethiopian Muslim protest movement under the controversial Anti-Terror law, on charges of terrorism and conspiracy to 'create an Islamic state' in Ethiopia. Two journalists, 10 activists and six members of the Ethiopian Arbitration Committee received sentences ranging from seven to 22 years of prison.53 This trial again led to demonstrations and was portrayed by some as a 'political spectacle designed to conceal the regime's re-indoctrination campaign and silence long-standing grievances of the Muslim population'.54 Interpreting this government legal action towards Muslim activists as part of an EPRDF strategy to delegitimise protest and silence certain journalists, activists and opposition leaders is no surprise, given the explicit political character these demonstrations and the government responses have acquired.

A final example of spatial expressions of political conflict between Ethiopian government and Muslim communities in Addis Ababa, is the latter's strategy of anti-government graffiti in Addis Ababa's public place. These are often only temporary, since they are frequently immediately removed by the EPRDF. Yet this silent but very visible way of urban protest, by which city walls display messages such as 'respect to the constitution' and 'respond to our request', has emerged as an original mechanism used by urban Muslim communities (especially the Intellectualist Movement) to claim public space. 55

\section{Media as a tool for constructing and deconstructing power and legitimacy}

In their power struggle, both the government and religious communities-Muslims as well as Christians - actively use media as a political tool. Abbink (2011) notes that this use of social and other media has fueled political tensions and has sharpened the polemics. The media landscape of Addis Ababa in the form of newspapers, broadcasting, Facebook, DVDs and YouTube has become the scene of extreme antigovernment as well as anti-Islam images and discourses.

When in 1991 steps were taken by the EPRDF to guarantee religious freedom in Ethiopia, the initiatives opened opportunities for alternative 
and religiously inspired media channels. All Ethiopian religious groups quickly began to produce new magazines and newspapers as well as (more recently) blogs and other forms of social media. Through these different channels, the Muslim communities express their religious, social and political claims to their rights and their position in Ethiopian society. As mentioned above, some Muslim communities are more prominently present in the media, and some groups are more explicitly political in their use of media, than others. For example, the publications of the Salafi and Tablighi movement will usually not engage in political matters but rather focus more on $D a^{\prime} w a$ (teaching the 'correct' form of Islam) and piousness (Østebø \& Shemsedin 2015). The only Muslim movement in Addis Ababa that is known for its emphasis on politics is the Intellectualist movement.

Especially since the structural protests began in 2011, several blog sites have emerged to attack the government's repressive actions against Muslim communities. $5^{6}$ The comments by one blogger provide a typical example:

We face a big bureaucratic challenge whenever we demand to build our mosques. Our children couldn't express their faith freely in government owned colleges and universities. Muslim charity organisations are falsely accused of expanding 'Wahhabism' and closed down. The leadership of the Majlis didn't say anything when these illegal measures were hurting the Muslim society, pointing to the Higher Council of Islamic Affairs in Ethiopia. 57

From the mid-1990s onwards, the Ethiopian government has increasingly intervened to close down Islamic media channels (Østebø 2010; Abbink 2011; Feyissa Dori 2011). Islamic periodicals are regularly censored by the government. These periodicals, distributed not only in Islamic institutes but also in shops, restaurants and elsewhere, are an important asset for the Muslim communities to shape their identity and public positions..$^{8}$ In 1998 only eight Islamic periodicals remained of the several dozen that emerged after 1991. By 2008 this number had been reduced to four (Salafiyah, al-Islam, Sawtul Islam and Quddis), and by 2011 they had all disappeared. After the escalation of the al-Ahbash and Aweliya incidents in 2011 the government cracked down on local Islamic production houses. They raided the privately owned Horizon press, which printed periodicals like Salafiyah and Sawtul Islam. The editor of the periodical Muslim Affairs was arrested together with the owner of Horizon press and two journalists went into hiding (Abbink $2014 \mathrm{~b}$ ). Other examples are the prohibition of television programmes, usually from Sudan or Egypt; Africa $T V$ based in Sudan is prohibited 
from broadcasting in Ethiopia, however due to satellite TV it is close to impossible for the government to control their broadcast. The Muslim communities in Addis Ababa argue that these actions contradict the freedom of religious expression and freedom of media as guaranteed in the Ethiopian constitution.59 It is important to note, however, that it is not only Islamic media that has suffered from censorship. Other religious periodicals and newspapers from Orthodox and Pentecostal origin have disappeared over the past two decades (Abbink 2011), justified as efforts to 'secure the secular values' of the Ethiopian state.

EPRDF, in its evolution towards a semi-authoritarian regime, has increasingly sought to control public information channels (internet, telephone) and media in general. When critically studying the most prominent discourses presented on the government-owned media channels, it cannot be denied that the topic of Islamic extremism and the threat of Islam in the Horn of Africa has received more and more media coverage. Through the EPRDF-owned newspapers and television channels, the role and responsibility of the Ethiopian government to combat this threat is continuously stressed. ${ }^{60}$

In the wake of the Aweliya incidents, the EPRDF distributed the documentary 'Jihadawi Harekat' ${ }^{61}$ (Jihadi movement, subtitled: Boko Haram in Ethiopia). One of the main claims of this documentary is the link between Ethiopian Islamic movements (such as the Salafi movement) to extremist groups all over Africa and the Mashrek. For example, it draws parallels between the Ethiopian Muslim civil rights movement (that originated from the Aweliya incident) and Islamic jihadist groups such as Boko Haram and al-Shabaab. The broadcast of this documentary strongly discredited the initial peaceful protest movement that had emerged around Aweliya College. However, this documentary was soon perceived by most Ethiopians (Muslims as well as Christians) as a clear example of propaganda, and it eventually backfired on the government. The documentary lost all credibility after various facts were leaked to the public, demonstrating that much of it had been intentionally orchestrated to delegitimise the Muslim Aweliya demonstrators. Eventually, a coalition of 33 (of the national total of $3^{6}$ ) political parties denounced the documentary as an orchestrated exaggeration of the facts to serve EPRDF propaganda and to justify the government's rude crackdown of the Muslim civil rights movement (Jawar et al. 2013).

Thus apart from reacting to the public religious media presence by curtailing and censoring Muslim media channels, the Ethiopian regime also actively engaged in the production and reproduction of a counter-discourse, from portraying Muslim communities as 'extremist' 
and 'radical', to castigate what the Ethiopian government understands under Islamic extremism, namely movements like Salafism and The Muslim brotherhood,, inspired by the post 9/11 discourse of the "war on terror'.

\section{O N C L U D I N G R E M A R K S}

The case of Addis Ababa perfectly illustrates the thesis that 'urban space is the product of conflict' (Massey 2005: 153). Political conflict between the government and the Muslim communities can be read from the urban landscape of Ethiopia's capital city. Conflicts over constructing and legalising mosques, public prayers and producing media discourse are the material outcomes of a complex struggle over public authority with historical roots in Ethiopia.

As this article has demonstrated, both parties engage in spatial mechanisms of presence and control. For the case of the Muslim communities, spatial claims in Addis Ababa are clearly visible and have drawn the attention of researchers such as Jon Abbink (2011) and Patrick Desplat (Desplat \& Schulz 2012). Most of the work on Islam and its presence in the public space is analysed by positing that Muslim communities are in opposition to Christian communities. This article complements this research by investigating in particular the agency and counter-agency of Muslim communities in relation to the Ethiopian government, and the ways in which the latter reinforces its power and control over the urban space. By government strategies such as putting the Majlis and other mosques under government control; closing schools, mosques and newspapers offices; deliberately leaving Muslim religious constructions in informal and illegal conditions; or publicly presenting Muslims as extremists, Muslims lose control over their most important assets of representation in the urban public space. State interference is routine in Addis Ababa's public life, but different examples demonstrate how, despite the strong state control over public urban space, Muslim communities not only 'break' or 'breach' into this urban space, but also achieve a certain extent of public visibility in the city, through infrastructure, practices and discourses. From the government side, apart from strategies of repression and censorship, the EPRDF also responds to Muslim spatial agency by counter-initiatives which attempt to reclaim the urban space. Through its 'counter-radicalisation' discourse, the Ethiopian government has shifted from mediating inter-religious conflicts to regulating religious practice, in which it increasingly adopts an anti-Islamic 
discourse (International Crisis Group 2016). Emerging from brutal government interference and from Muslim polemic messages, the urban landscape of Addis Ababa has become a vibrant arena of intimidation and confrontation. Urban public spaces are being made and unmade as part of political strategies of presence and dominance.

All over the world, spatial translations of ethnic or religious tensions turn cities into fragmented landscapes. Competing claims between governments and religious communities over the control of urban public space are manifest in very different settings. Sensitive debates over the recognition and construction of Islamic schools and mosques in various cities of Western Europe present a clear example. Political crisis over the balance between religious freedom and the principles of the secular state yields intense debates that influence urban and national planning policies (Uitermark et al. 2005; Hopkins \& Gal 2009). These dynamics are always both locally as well as globally inspired, and emerge from both local historical trajectories of Muslim communities as well as from the influence of global post-9/1 1 discourses about Islam. The current political demands of Addis Ababa's Muslim communities have to be understood in the context of the connection of local Islamic movements to transnational and more political forms of Islam. At the same time, local anti-Islamic sentiments in Addis Ababa and the government's acts of repression have been strongly fuelled by the global War on Terror. Within the Horn of Africa, Ethiopia is considered an anti-terror stronghold and an 'ally to the West' (Østebø 2013). ${ }^{62}$ In this context, Ethiopia not only receives substantial foreign support to 'fight terrorism', but also receives political legitimisation of its regime (Feyissa Dori 2011; Jawar et al. 2013). As has been demonstrated by many scholars in other cases, the 'war-onterror' discourse, easily manipulated and actively given shape through the government-controlled media, proved to be a welcome means through which the EPRDF could castigate Islam in Ethiopia and at the same time reinforce its own power position. This has provided the regime with a political framework that justified repressive actions taken against Muslim communities in Addis Ababa and that led to an increasing 'policy of containment' by which it has sought to extend control over Islamist movements (Østebø 2013). More recent dynamics in Ethiopia following Islamic State execution of Ethiopians in Libya, and further debates on ISIS influences in Ethiopia, have indisputably additionally reinforced the government's repressive attitude towards Muslim communities. 
By researching urban fragmentation from a spatial perspective, investigating the dynamic use and manipulation of the urban material, discursive and performative landscape, this paper offers an original contribution to the current debates on the configuration of political identities and public authority in urban Ethiopia. It has demonstrated how the urban landscape is a site of regulation and control, and how the closer analysis of interventions in this landscape by all actors involved in the struggle for control and dominance can provide insights into the ways in which power and authority are locally produced.

\section{NOT E S}

1. In this article, talking about Muslim communities (in plural), we refer to the multitude of different Islamic groups and fractures that exist in Addis Ababa today. However, as an analytical category, we present them as one in their more or less unified struggle to counter EPRDF's strategies to control them. Cross-movement actions have been the norm for Ethiopian Muslims in their approach on the government.

2. Ethiopian People's Revolutionary Democratic Front.

3. Communist regime which took power in Ethiopia after the revolution in 1974 and which was overthrown in 1991 .

4. Ethiopian government, 'Proclamation No. 1: the constitution of the federal Democratic Republic of Ethiopia', 1995, p. 126.

5. Christians did not regain their previous position as religion of the state. The new secular state remained free from direct religious political involvement and took active steps to maintain the separation of state and religion.

6. Restrictions on the Hajj (pilgrimage to Mecca) were abolished and religious literature could from then on be exported and imported freely (Østebø 2013).

7. To a certain extent this study builds on the extensive work done by Jon Abbink on state-religious relations in Ethiopia (Abbink 2011, 2014a, 2014b).

8. For an overview of the most important trends of the 'spatial turn' in studies of Islam and Muslim communities: see Desplat \& Schulz (2012).

9. Also inspired by the work of Fiona Williamson (2010) on the locality of political agency and the insights of Michel Foucault (1984) on the intersection between space, power and social practice.

10. Other case studies have beautifully demonstrated the importance of materiality in religious communities' experience of marginalization and oppression (Larkin 2013; Graham 2002; Hart $1988)$.

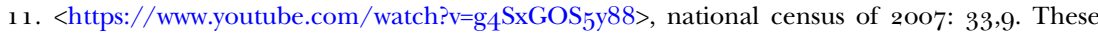
numbers, however, have strongly been contested by the Ethiopian Muslim communities (Abink 2011: 270).

12. For an overview of the history of Islam in Ethiopia: see Hussein (1993, 2007) and Feyissa Dori (2013). Although today more united than before (in their common 'struggle' against the Ethiopian Government) the Ethiopian Muslim communities are not without internal fragmentation. See for example Østebø (2010), Abbink (2011), Feyissa Dori (2011) on the tensions between 'mainstream' and 'radical' Islamic movements.

13. Interview with Muslim professor at the Department of Languages, Addis Ababa University $(5.2 .2014)$.

14. This however does not mean that these boroughs or sub-cities are religiously homogeneous.

15. Interview with Muslim professor at Human Rights Department of Addis Ababa University (12.2.2014). Interview with Muslim reporter and author of two books on mosques in Addis Ababa (24.1.2014).

16. The expansion of Salafist movements is increasingly creating tensions within the Muslim community (Interview with reporter and cameraman $3 \cdot 2.2014$ ). 
17. Østebø (2013); Interview with a Christian researcher working on minority groups in Ethiopia including Ethiopian Muslims (28.1.14).

18. This distrust by the local Muslim community as well as by the Muslim Ethiopian diaspora can be read from the following blog: <http://blog.ethiopianmuslims.net/?p=2169>, consulted 12.4.2014. See also Abbink (2014a).

19. During one of these training sessions, around 200 people were arrested after dropping out, which suggests that this campaign was not always attended voluntarily (Østebø 2013). Imams who refused to participate in training organised in the Sandafa Military Training Camp had taken their leadership from regional or zonal Majlis or mosques (Jawar et al. 2013).

20. Interview with Muslim professor at Human Rights Department of Addis Ababa University (15.2.2014); Interview with Muslim employee of Institute of Ethiopian Studies (14.2.2014); Interview with Muslim professor at the Department of Anthropology, Addis Ababa University $(3.2 .2014)$.

21. A detailed overview of the trajectory of different events and their underlying dynamics is presented by Jon Abbink (2014a: 252-353).

22. After withdrawing the licence of its main sponsor, the Saudi based Muslim World League "under the suspicion that they were engaged in "religious propaganda" (Abbink 2014a: 353).

23. Interview with Muslim professor at the Human Rights Department of Addis Ababa University $(3.2 .2014)$.

24. Interview with a Christian researcher working on minority groups in Ethiopia including Ethiopian Muslims (2.2.2014). See Abbink (2014a) on the organization of the protest movements and their political demands.

25. These are figures according to the World Population Review $<$ http://worldpopulationreview. $\mathrm{com} /$ countries/ethiopia-population/>. The last official national census dates from 2007, with $2,739,511$ inhabitants.

26. According to the Addis Ababa Master Plan, 'about a quarter of all housing units in Addis Ababa have been built illegally and informally' (Addis Ababa revised Master Plan Proposals: Draft summary December 200o, p. 30).

27. Office for the revision of the Addis Ababa Master plan, Addis Ababa revised Master Plan Proposals: Draft summary December 20oo, Addis Ababa, Addis Ababa city government (2001), p. 46 .

28. Jon Abbink, in his research on Muslim-Christian relations in Ethiopia, argues that religious identities are becoming increasingly dominant as people's primary public identity, impacting the 'public sphere' where religious identities are being presented and contested in a self-consciously polemical fashion (Abbink 2011, 2014b).

29. As Desplat has convincingly argued with regards to religious geographies and Muslim practices of place-making, a place is at once a performative act (performed landscape) and a structuring order; it is a medium through which social urban life is affected (Desplat 2005).

3o. Interview with a Muslim reporter and author of two books on history of mosques in Addis Ababa (24.1.2014); Interview with a Muslim professor at the Human Rights Department of Addis Ababa University (28.1.2014); Interview with a Muslim reporter and cameraman (8.3.2014).

31. Focus group of seven mosque participants at Anwar Mosque (13.3.2014).

32. Based on field observation and informal conversations with mosque participants.

33. Interview Government Official city planning (4.3.2014). During this interview, when critical questions were asked on the procedure of land allocation to construct mosques, the atmosphere became increasingly tense and the translator was being threatened.

34. Interview with a Muslim political scientist at Addis Ababa University, also an important figure in the intellectualist movement $(3.2 .2014)$.

35. Interview with a Christian researcher working on minority groups in Ethiopia including Ethiopian Muslims (2.2.2014).

36 . Interview with a Muslim reporter and cameraman (8.3.2014).

37. The equivalent of around $€ 7,5$ oo.

38 . In an interview with a Muslim reporter and cameraman (13.2.2014) it was mentioned that the main person in charge of this construction was imprisoned (13.2.2014).

39. Muslim reporter and cameraman (8.3.2014).

40. Interview with Muslim reporter and cameraman (8.3.2014).

41. Interview with a Muslim reporter and cameraman (13.2.2014).

42. This deployment of security services strongly increased after the wave of demonstrations in 2011 , see footnote 43 . 
43. Interview with a Muslim political scientist at Addis Ababa University, also an important figure in the intellectualist movement (3.2.2014).

44. Interview with a business man (Muslim) 10.3.2014. Interview with Muslim reporter and cameraman $(19 \cdot 2.2014)$.

45. Interview with a Muslim professor at the Human Rights Department of Addis Ababa University (12.2.2014); Interview with Muslim reporter and cameraman (13.2.2014).

46. Focus group of five female Muslim students (24.2.2014).

47. Focus group of five female Muslim students (24.2.2014); Interview with a Muslim professor at the Human Rights Department of Addis Ababa University (12.2.2014); Interview with a Muslim reporter and cameraman $(13 \cdot 2.2014)$.

48. The power of this form of spatial agency has become extremely visible during the Arab Spring in 2010 .

49. Interview with a Muslim female teacher in secondary education (13.2.14); Interview with a Muslim professor at the Department of Anthropology of Addis Ababa University (3.2.2014); Interview with a Muslim professor at the Human Rights Department of Addis Ababa University (12/02/2014); Focus group of five female Muslim students (24.2.2014).

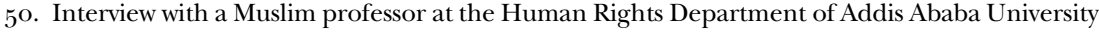
(12.2.2014). Interview with a Muslim reporter and author of two books on mosques in Addis $(24.1 .2014)$.

$5^{1}$. Interview with a Muslim female teacher in secondary education (13.2.2014); Interview with a Muslim professor at the Department of Anthropology of Addis Ababa University (3.2.2014); Interview with a Muslim professor at the Human Rights Department of Addis Ababa University (12.2.2014); Focus group of five female Muslim students (24.2.2014).

52. Interview with a Muslim female teacher in secondary education (13.2.2014).

53. Reuters: 'Ethiopia hands lengthy prison terms to Muslim activists' <http://www.reuters.com/ article/us-ethiopia-arrests-idUSKCNoQ82AC2015o803> (accessed 14.5.2016); Al Jazeera America: 'Ethiopia Politicizes Courts to Strangle Dissent' <http://america.aljazeera.com/opinions/2015/7/ ethiopia-politicizes-courts-to-strangle-dissent.html $>$ (accessed 14/05/16).

54. Al Jazeera America: Ethiopia Politicizes Courts to Strangle Dissent <http://america.aljazeera. com/opinions $/ 2015 / 7$ /ethiopia-politicizes-courts-to-strangle-dissent.html $>$ (accessed 14.5.16).

55. See: 'Let our voice be heard' <https://www.facebook.com/DimtsachinYisemaEnglish/ photos/a.489440981150846.1073741825.328062930621986/489441154484162/> (accessed 14.5.2016); own observations.

56. See for example: <http://blog.ethiopianmuslims.net/? $\mathrm{p}=2169>$ (accessed 12.4.2014).

57. Blog for Ethiopian Muslims on which they can express their ideas and frustrations <http:// blog.ethiopianmuslims.net/? $\mathrm{p}=2169>($ accessed 12.4 .2014$)$.

$5^{8}$. For more detail on early periodicals and the subject they cover, see Hussein (1997).

59. Ethiopian Government, 'Proclamation No. 590: A proclamation to provide for freedom of the mass media and access to information' in Federal Negarit Gazeta, 20o8, p. 4. Ethiopian government, 'Proclamation No. 1: the constitution of the federal Democratic Republic of Ethiopia', 1995, p. 126.

6o. The Ethiopian Herald, 'The need to create terrorist intolerant society', 22.1 2.2007; The Ethiopian Herald, 'Ethiopia said showing new way of solving problems with terrorism', 28.1 2.20o6; The Ethiopian Herald, 'Fundamentalist force in Somalia declares intensified attacks on Ethiopia', 13.12.2006; The Ethiopian Herald, 'Terrorism: a menace to world peace', 9.1.2005.

61. See <https://www.youtube.com/watch?v=g4 $\mathrm{SxGOS}_{5} \mathrm{y} 88>($ accessed 27.4.2014).

62. The Ethiopian Herald, 'Ethiopia said showing new way of solving problems with terrorism', 28.12 .2006 .

\section{REFER E N E S}

Abbink, J. 2011 . 'Religion in public spaces: emerging Muslim-Christian polemics in Ethiopia', African Affairs 1 10: $253^{-74}$.

Abbink, J. 2014a. 'Religion and politics in Africa: the future of "the secular", Africa Spectrum 49: 83106.

Abbink, J. 2014b. 'Religious freedom and the political order: the Ethiopian 'secular state' and the containment of Muslim identity politics', Journal of Eastern African Studies 8: 346-65.

Abdellah, A. 2007. Hayat Directory. Addis Ababa, January. 
Abdulwehab, K. 2011. 'The history of Addis Ababa mosques', Annales d'Ethiopie 26: 311-18.

Büscher, K. 2012 . 'Urban governance beyond the state: practices of informal urban regulation in the city of Goma, Eastern D.R. Congo', Urban Forum 23: 483-99.

Büscher, K. 2015. 'Reading urban landscapes of war and peace: the case of Goma, DRC', in A. Björkdahl \& S. Buckley-Zitsel, eds. Spatializing Peace and Conflict: Mapping the production of Places, Sites and Scales of Violence. Basingstoke: Palgrave Macmillan, 79-97.

Desplat, P. 2005. 'The articulation of religious identities and their boundaries in Ethiopia: labelling differences and processes of contextualization in Islam', Journal of Religion in Africa, $35^{:} 4^{82-5} 5_{5}$.

Desplat, P. \& D. Schulz. 201 2. Prayer in the city: the making of Muslim sacred places and urban life. Bielefeld: Transaction Publishers.

Di Nunzio, M. 2012. 'We are good at surviving: street hustling in Addis Ababa's inner city', Urban Forum 23: 433-47.

Feyissa Dori, D. 2011. 'The potential for and signs of religious radicalization in Ethiopia'. Addis Ababa: 45 .

Feyissa Dori, D. 2013. 'Muslims struggling of recognition in contemporary Ethiopia'. Addis Ababa: $25-46$.

Foucault, M. 1984. Of other spaces: utopias and heterotopias ('Des Espace Autres', March 1967, Translated from the French by Jay Miskowiec). Architecture/Mouvement/Continuité October 1984.

Gale, R. 2004. 'The multicultural city and politics of religious architecture: urban planning, mosques and meaning-making in Birmingham, UK', Built Environment 30: 30-44.

Gale, R. \& Naylor, S. 2002. 'Religion, planning and the city: the spatial politics of ethnic minority expression in British cities and towns', Ethnicities 2: $387-409$.

Garmany, J. 2010. 'Religion and governmentality: understanding governance in urban Brazil', Geoforum 41: 908-18.

Graham, S. 2002. 'On technology, infrastructure, and the contemporary urban condition: a response to Coutard', International Journal of Urban and Regional Research 26: 175-82.

Hart, D. M. 1988. 'Political manipulation of urban space: the razing of District Six, Cape Town', Urban Geography 6: 6o3-88.

Holloway, J. \& O. Valins. 2002. 'Placing religion and spirituality in geography', Social and Cultural Geography 3: $5^{-10 .}$

Hopkins, P. \& R. Gal. 2009. Muslims in Britain: race, place and identities. Edinburgh: Edinburgh University Press.

Hussein, A. 1993. Islam and Islamic discourse in Ethiopia. Ibadan: Spectrum Books.

Hussein, A. 1997. The historiography of Islam in Ethiopia. London: Centre of Ethiopian studies.

Hussein, A. 2006. 'Coexistence and/or confrontation? Towards a reappraisal of Christian-Muslim encounter in Contemporary Ethiopia', Journal of Religion in Africa 36: 4-22.

Hussein, A. 2007. 'Reflections on historical and contemporary Islam in Ethiopia and Somalia: a comparative and contrastive overview', Journal of Ethiopian Studies 40: 261-76.

International Crisis Group. 2016. 'Ethiopia: governing the faithful', ICG Africa Briefing No. 117.

Jawar, M. et al. 2013. The Civil Rights Movement of Ethiopian Muslims. Belgium, LEBMA vzw.

Jenkins, P. 2009. 'African cities: competing claims on urban land', in F. Locatelli \& P. Nugent, eds. African Cities: competing claims on urban spaces. Leiden: Brill, 81-107.

Kong, L. 1990. 'Geography and religion: trends and prospects', Progress in Human Geography 14: $355^{-71}$.

Kong, L. 2001. 'Mapping 'new' geographies of religion: politics and poetics in modernity', Progress in Human Geography 25: $211-33$.

Larkin, B. 2013. 'The politics and poetics of infrastructure', Annual Review of Anthropology 42: 327-43.

Lefort, R. 2012. 'Free market economy, 'development state' and party-state hegemony in Ethiopia: the case of the "model farmers", Journal of Modern African Studies 50: 681-7o6.

Locatelli, F. \& P. Nugent. 20o9. African Cities: competing claims on urban spaces. Leiden: Brill.

Mabin, A. 1989. 'Struggle for the city: urbanisation and political strategies of the South African state', Social Dynamics 15: 1-28.

Massey, D. 2005. For Space. London: Sage.

Masud, M. K. 2ooo. Travellers in Faith. Leiden: Brill.

Planel, S. \& M. Bridonneau. 2015. 'Global Ethiopia: scales and power shifts', EchoGeo, 31. <https:// echogeo.revues.org/14219>.

Olson, E., P. Hopkins, R. Pain \& G. Vincett. 2013. 'Retheorizing the postsecular present: embodiment, spatial transcendence, and challenges to authenticity among young Christians in Glasgow, Scotland', Annals of the Association of American Geographers, 103: 1421-36. 
Østebø, T. 2008. 'The question of becoming: Islamic reform movements in contemporary Ethiopia', Journal of Religion in Africa 38: 416-46.

Østebø, T. 2010. 'Islamism in the Horn of Africa: assessing ideology, actors and objectives', ILPI Report, Norway.

Østebø, T. 2013. 'Islam and state relations in Ethiopia: from containment to the production of a governmental Islam', Journal of American Academy of Religion 81: 1029-6o.

Østebø, T. \& W. Shemsedin. 2015. 'The Intellectualist Movement in Ethiopia, the Muslim Brotherhood and the issue of moderation', NOREF report, March 2015. <http://www.peacebuilding.no/var/ ezflow_site/storage/original/application/ $489645^{6} 55^{8 \mathrm{eb}} 5^{\mathrm{o}} 8 \mathrm{oa} 876143^{62} 5$ da 37 b.pdf>

Sadeh, E. 2010. The Politics of Space: a survey. London: Routledge.

Stockmans, J. 2014. 'Ethiopian Muslims in the public space of Addis Ababa since 1991', Master's Dissertation.

Sumeya, A. 2012. History of Addis Ababa Mosques from Minilik III- EPRDF. Addis Ababa.

Uitermark, J., U. Rossi \& H. Van Houtem. 2005. 'Reinventing multiculturalism: urban citizenship and the negotiation of ethnic diversity in Amsterdam', International Journal of Urban and Regional Research 29: 622-40.

Van der Beken, C. 2010. Unity in Diversity - Federalism as a Mechanism to Accommodate Ethnic Diversity: the case of Ethiopia. Munster: Lit Verlag.

Williamson, F. 2010. Locating Agency: space, power and popular politics. Newcastle: Cambridge Scholars Publishing. 